\title{
Control of Dollar Spot of Creeping Bentgrass Caused by an Isolate of Sclerotinia homoeocarpa Resistant to Benzimidazole and Demethylation-Inhibitor Fungicides
}

\author{
L. L. Burpee, Department of Plant Pathology, University of Georgia, Georgia Experiment Station, Griffin 30223
}

\begin{abstract}
Burpee, L. L. 1997. Control of dollar spot of creeping bentgrass caused by an isolate of Sclerotinia homoeocarpa resistant to benzimidazole and demethylation-inhibitor fungicides. Plant Dis. 81:1259-1263.

The effects of fungicides were studied on two isolates of Sclerotinia homoeocarpa that differed in fungicide sensitivity. Concentrations of benzimidazole (benomyl and thiophanate-methyl), demethylation inhibitor (fenarimol, propiconazole, and triadimefon), and nitrile (chlorothalonil) fungicides required to inhibit mycelial growth in vitro by 50 and $90 \%$ (effective concentration; $\mathrm{EC}_{50,90}$ ) were significantly greater for isolate S088 than for isolate S084. No differences were observed in the $\mathrm{EC}_{50,90}$ values of a pyridylaniline (fluazinam) or dicarboximide (iprodione) fungicide. I23n field tests conducted on creeping bentgrass, S088 had a significantly shorter incubation period than S084 in plots treated with propiconazole applied at 0.2 or $0.8 \mathrm{~kg} \mathrm{a.i.} \mathrm{ha-1}$ in 1994 or $0.4 \mathrm{~kg}$ a.i. ha- ${ }^{-1}$ in 1995, thiophanate-methyl applied at 1.5 or $3.0 \mathrm{~kg}$ a.i. ha ${ }^{-1}$ in 1994 and 1995 , or a tank-mix of propiconazole and iprodione applied at $1.6+0.8 \mathrm{~kg} \mathrm{a}$.i. ha $\mathrm{ha}^{-1}$ in 1994 . No differences in incubation periods occurred in plots treated with chlorothalonil or iprodione in either year, or with fluazinam in 1995 and 1996. Fewer days were required to reach 5\% disease severity in turf inoculated with isolate S088, compared to isolate S084, in plots treated with propiconazole, thiophanate-methyl, or certain tank-mixes containing propiconazole, in 1994 and 1995. Several treatments, including propiconazole, thiophanate-methyl, and fluazinam, resulted in suppression of disease caused by isolate S084 to less than 5\% severity for more than 21 days, while only fluazinam applied at 1.6 or $3.2 \mathrm{~kg}$ a.i. ha ${ }^{-1}$ provided more than 21 days of disease suppression in turf inoculated with either of the isolates tested. Slope coefficients from linear regressions between incubation period or days to $5 \%$ disease and concentrations of fungicide applied in 1996 were significantly different for isolate S084 compared to isolate S088 in plots treated with propiconazole, but not in plots treated with fluazinam.
\end{abstract}

Dollar spot, caused by Sclerotinia homoeocarpa F.T. Bennett, is a serious disease of turfgrasses grown in temperate and subtropical regions (5). The fungus incites a foliar blight during periods of extended leaf wetness and temperatures of 15 to $30^{\circ} \mathrm{C}$ (11). Infection results in white to straw-colored lesions that coalesce on several tillers to produce spots 1 to $5 \mathrm{~cm}$ in diameter in turfgrass stands. All common species of warm- and cool-season turfgrasses are susceptible to S. homoeocarpa (4).

Dollar spot is a chronic problem on many golf courses, where infected turf can limit the uniformity of putting greens and fairways. In addition, the disease often decreases the aesthetic value of public and private lawns. Strategies for management of dollar spot on these and other sites include an increase in the rate and frequency of nitrogen fertilization; the pruning of trees and shrubs to limit shade, increase air circulation, and decrease the duration of turf wetness; establishment of grass culti-

Corresponding author: L. L. Burpee

Accepted for publication 16 July 1997.

Publication no. D-1997-0825-05R

(C) 1997 The American Phytopathological Society vars that exhibit reduced susceptibility to Sclerotinia; and the application of fungicides (2). The latter practice is common on sites such as golf courses, where the threshold of acceptable disease incidence is particularly low (11).

More than 15 compounds representing at least seven chemically-related groups are registered for control of dollar spot in the United States (5). Fungicides in two of these groups, the demethylation inhibitors (DMIs) and the benzimidazoles, are systemic in turfgrasses and provide longer periods of control than nonsystemic materials (11). Most nonsystemic compounds have multi-site modes of action in the cells of fungi, while DMI and benzimidazole fungicides are site-specific inhibitors (8). This specificity, along with an intense and frequent use of chemical controls on turfgrass, has led to the selection of $S$. homoeocarpa strains that exhibit resistance to fungicides in the DMI $(6,12)$ or benzimidazole (13) groups.

Results of preliminary tests with three DMI-resistant isolates of $S$. homoeocarpa showed that each isolate also was resistant to benomyl (L. L. Burpee, unpublished). The effective concentration (EC) $)_{50}$ value of benomyl for the DMI resistant isolates was more than $800 \times$ that of a DMI-sensitive isolate. Similar observations have been made with other DMI-resistant isolates (J.
M. Vargas, personal communication). Golembiewski et al. (6) found that applications of the nonsystemic fungicide chlorothalonil at 10-day intervals provided acceptable control of dollar spot caused by a DMI-resistant strain. However, it is questionable whether chlorothalonil or other nonsystemic fungicides can provide the extended control (more than 21 days) produced by systemic materials prior to the development of resistance (11). Suppression of dollar spot for 3 weeks or longer is important to golf course superintendents who have limited budgets for disease control on extensive turf areas such as fairways. Therefore, the objective of this study was to compare the efficacies of the fungicides chlorothalonil, iprodione, and fluazinam with those of propiconazole (a DMI) and thiophanate-methyl (a benzimidazole) for control of dollar spot caused by either a fungicide-sensitive isolate of $S$. homoeocarpa, or an isolate resistant to both DMI and benzimidazole fungicides.

\section{MATERIALS AND METHODS}

Laboratory studies. The effect of fungicides (Table 1) was studied in vitro on the growth of 2 isolates of $S$. homoeocarpa. Isolate S084 was collected in 1980 from a creeping bentgrass (Agrostis palustris Huds.) golf green in State College, Pennsylvania, and isolate S088 was isolated in 1993 from bentgrass collected from a golf fairway in Chicago, Illinois.

Commercial formulations of the fungicides benomyl, chlorothalonil, fenarimol, iprodione, propiconazole, and triadimefon were diluted to concentrations of 0.01 to $100 \mu \mathrm{g} \mathrm{ml}^{-1}$, at approximately $4 \times$ intervals, in cooled $\left(50^{\circ} \mathrm{C}\right)$ potato dextrose agar (PDA, Difco Laboratories, Detroit) and poured into 9-cm-diameter petri dishes. Concentrations of thiophanate-methyl ranged from 0.1 to $1,000 \mu \mathrm{g} \mathrm{ml}^{-1}$ at $10 \times$ intervals, while concentrations of fluazinam ranged from 0.01 to $0.5 \mathrm{ng} \mathrm{ml}^{-1}$ at approximately $2 \times$ intervals. Dishes of nonamended PDA served as controls. Sixmm-diameter mycelial plugs from the margins of colonies of $S$. homoeocarpa (isolates S084 and S088) growing on PDA were transferred to the center of each dish and incubated at $22^{\circ} \mathrm{C}$ in the dark. Colony diameters were measured to the nearest millimeter after $72 \mathrm{~h}$ of incubation. Each treatment was replicated three times, and the experiment was repeated once. EC values, representing reductions of mycelial growth by 50 and $90 \%$, were determined for each replicate by regressing probit 
transformed percent inhibition of growth against $\log _{10}$ concentrations of the fungicides. $\mathrm{EC}_{90}$ values more than $100 \mu \mathrm{g} \mathrm{ml}^{-1}$ for benomyl and fenarimol were determined by extrapolation. Replicate values of $\mathrm{EC}_{50}$ and $\mathrm{EC}_{90}$ were subjected to analysis of variance and means were separated by an $F$ test at $P \leq 0.05$.

Field studies. Experiments designed to assess the effects of fungicides on dollar spot caused by isolates S084 and S088 of $S$. homoeocarpa were conducted on a sward of creeping bentgrass cv. Penncross at the Georgia Experiment Station, Griffin, Georgia, in September 1994 and 1995, and May 1996. The turfgrass was established from seed in 1990 on a sand-based root zone, mowed to a height of $5 \mathrm{~mm}$ three times per week, and otherwise maintained as prescribed for bentgrass golf greens (1). Treatment plots were arranged on the green in a split-plot design with four replicates. Inoculum of each isolate was applied separately to main plots, and fungicide treat- ments (Table 2, Figs. 1 and 2) were applied individually or as tank mixtures to subplots. Subplots measured 1 by $1 \mathrm{~m}$ in each trial, and main plots were $1 \mathrm{~m}$ wide and 13 , 16, and $19 \mathrm{~m}$ long in 1994, 1995, and 1996, respectively. Each year, plots were placed in a different area of the green to prevent problems associated with residual treatment effects. In addition, to limit spread of the $S$. homoeocarpa isolates throughout the green, the turf was treated at 14- to 21-day intervals with chlorothalonil at $10.2 \mathrm{~kg}$ a.i. $\mathrm{ha}^{-1}$ or iprodione at $3.1 \mathrm{~kg}$ a.i. ha ${ }^{-1}$ immediately after and up to 3 weeks before each study. Any dollar spot that may have developed from residual inoculum in the green was probably caused by isolate S084, because this was the only isolate used on the green in dollar spot studies over the past 6 years.

Fungicide treatments were applied once for each experiment on 21 September 1994, 26 September 1995, and 7 May 1996. No subsequent applications were

Table 1. Fungicides studied in vitro on growth of Sclerotinia homoeocarpa

\begin{tabular}{|c|c|c|c|}
\hline Fungicide & Chemical group & $\begin{array}{l}\text { Commercial } \\
\text { formulation }^{y}\end{array}$ & Manufacturer \\
\hline Benomyl & Benzimidazole & Benlate 50WP & E. I. du Pont de Nemours Co. \\
\hline Chlorothalonil & Nitrile & Daconil Ultrex 82.5DG & ISK Biosciences Corporation \\
\hline Fenarimol & Pyrimidine $(\mathrm{DMI})^{\mathrm{z}}$ & Rubigan A.S. 1.0AS & Dow Elanco \\
\hline Fluazinam & Pyridylaniline & Fluazinam $500 \mathrm{~F}$ & ISK Biosciences Corporation \\
\hline Iprodione & Carboximide & Chipco 26019 Flo $23.3 \mathrm{~F}$ & AgrEvo USA Corporation \\
\hline Propiconazole & Triazole $(\mathrm{DMI})^{\mathrm{z}}$ & Banner 1.1E & Ciba-Geigy Corporation \\
\hline $\begin{array}{l}\text { Thiophanate- } \\
\text { methyl }\end{array}$ & Benzimidazole & Systec 1998 85WDG & Regal Chemical Company \\
\hline Triadimefon & Triazole $(\mathrm{DMI})^{\mathrm{z}}$ & Bayleton 25WP & Bayer Corporation \\
\hline
\end{tabular}

${ }^{\mathrm{y}}$ Abbreviations for formulations: $\mathrm{DG}=$ dispersible granule, $\mathrm{E}=$ emulsion, $\mathrm{F}=$ flowable, $\mathrm{WDG}=$ wettable dispersible granule, $\mathrm{WP}=$ wettable powder.

${ }^{\mathrm{z}} \mathrm{DMI}=$ demethylation inhibitor.

Table 2. Effect of fungicides over 2 years on the incubation period in creeping bentgrass of Sclerotinia homoeocarpa isolates that differ in sensitivity in vitro to several fungicides

\begin{tabular}{|c|c|c|c|c|c|}
\hline \multirow[b]{3}{*}{ Treatment } & \multirow[b]{3}{*}{ Rate (kg a.i. ha-1) } & \multicolumn{4}{|c|}{ Incubation period (days) } \\
\hline & & \multicolumn{2}{|c|}{$1994^{w}$} & \multicolumn{2}{|c|}{$1995^{w}$} \\
\hline & & S084 & S088 & S084 & S088 \\
\hline Chlorothalonil & 4.8 & $6.5 \mathrm{c}^{\mathrm{x}}$ & $6.8 \mathrm{c}$ & $9.5 \mathrm{c}$ & $9.3 \mathrm{c}$ \\
\hline Chlorothalonil & 9.5 & $7.3 \mathrm{c}$ & $8.8 \mathrm{~b}$ & $10.0 \mathrm{c}$ & $10.0 \mathrm{c}$ \\
\hline Iprodione & 1.6 & $5.5 \mathrm{~d}$ & $5.3 \mathrm{~d}$ & $7.0 \mathrm{~d}$ & $7.8 \mathrm{~d}$ \\
\hline Iprodione & 3.1 & $6.5 \mathrm{c}$ & $6.3 \mathrm{c}$ & $7.0 \mathrm{~d}$ & $7.3 \mathrm{~d}$ \\
\hline Propiconazole & 0.2 & $9.3 c^{y}$ & $5.3 \mathrm{~d}$ & $7.5 \mathrm{~d}$ & $7.0 \mathrm{~d}$ \\
\hline Propiconazole & 0.4 &.$^{2}$ & & $9.3 \mathrm{c}$ & $6.5 \mathrm{~d}$ \\
\hline Propiconazole & 0.8 & $12.8 \mathrm{~b}$ & $6.3 \mathrm{c}$ & $1 \overline{0.5 \mathrm{c}}$ & $8.0 \mathrm{~d}$ \\
\hline Chlorothalonil + propiconazole & $4.8+0.2$ & $\overline{10.8 \mathrm{~b}}$ & $\overline{8.3 \mathrm{~b}}$ & $10.5 \mathrm{c}$ & $9.5 \mathrm{c}$ \\
\hline Chlorothalonil + propiconazole & $4.8+0.8$ & $13.5 \mathrm{~b}$ & $10.0 \mathrm{a}$ & $12.3 \mathrm{c}$ & $11.0 \mathrm{c}$ \\
\hline Iprodione + propiconazole & $1.6+0.2$ & $5.8 \mathrm{~d}$ & $5.0 \mathrm{~d}$ & $9.0 \mathrm{c}$ & $9.3 \mathrm{c}$ \\
\hline Iprodione + propiconazole & $1.6+0.8$ & $13.5 \mathrm{~b}$ & $\underline{8.0 \mathrm{~b}}$ & $10.5 \mathrm{c}$ & $9.5 \mathrm{c}$ \\
\hline Thiophanate-methyl & 1.5 & $13.0 \mathrm{~b}$ & $4.0 \mathrm{e}$ & $17.0 \mathrm{~b}$ & $6.0 \mathrm{~d}$ \\
\hline Thiophanate-methyl & 3.0 & $\overline{20.5 \mathrm{a}}$ & $\overline{4.0 \mathrm{e}}$ & $\overline{18.0 \mathrm{~b}}$ & $\overline{5.8 \mathrm{~d}}$ \\
\hline Fluazinam & 1.6 & $\ldots$ & $\ldots$ & $18.8 \mathrm{~b}$ & $21.8 \mathrm{~b}$ \\
\hline Fluazinam & 3.2 & $\ldots$ & $\ldots$ & $27.0 \mathrm{a}$ & $27.3 \mathrm{a}$ \\
\hline Nontreated & $\ldots$ & $5.0 \mathrm{~d}$ & $4.0 \mathrm{e}$ & $7.0 \mathrm{~d}$ & $5.8 \mathrm{~d}$ \\
\hline
\end{tabular}

${ }^{\mathrm{w}}$ Isolate S088 was significantly less sensitive in vitro to the fungicides benomyl, chlorothalonil, fenarimol, propiconazole, thiophanate-methyl, and triadimefon than isolate S084.

${ }^{x}$ Within a column, values followed by the same letter are not significantly different at $\alpha=0.05$ according to the Scott-Knott cluster analysis procedure.

${ }^{y}$ Within a treatment, underlined values are significantly different at $P \leq 0.05$ according to orthogonal contrast analysis.

${ }^{\mathrm{z}}$ Treatment not applied.

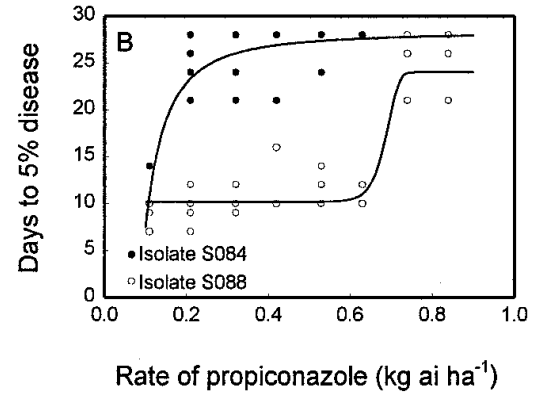

Fig. 1. Effect of propiconazole on (A) the incubation periods of isolates of Sclerotinia homoeocarpa that differ in fungicide sensitivity, and on (B) days to 5\% severity of dollar spot caused by the isolates. Lines are regression models: incubation period of isolate S084 = $3.80+30.16$ (fungicide rate), $r^{2}=0.85$; incubation period of isolate $\mathrm{S} 088=3.59+7.25$ (fungicide rate), $r^{2}=0.63$. Days to $5 \%$ disease caused by isolate $\mathrm{S} 084=27.94+0.31$ (fungicide rate) $+\left(-0.21\right.$ [fungicide rate $^{2}$ ] $), r^{2}=$ 0.87 ; days to $5 \%$ disease caused by isolate $\mathrm{S} 088=24.03-13.84$ exp. $(-23399.55$ [fungicide rate 27.81]), $r^{2}=0.87$. Slope coefficients of all models were significant at $P<$ 0.05 . 
Visual estimates of disease severity, using the Horsfall-Barratt rating scale (7), were made at approximately 3-day intervals after fungicide application. In 1994 and 1995, these estimates were used to approximate the incubation period of $S$. homoeocarpa and the number days required to reach $5 \%$ disease severity in each plot. Values were subjected to a factorial analysis of variance, and means were statistically separated using the Scott-Knott cluster analysis procedure (10) and orthogonal contrast analysis (9) at values of $\alpha$ and $P \leq 0.05$, respectively. In 1996, regression analysis was used to assess dose response relationships for propiconazole and fluazinam on components of epidemics caused by the 2 isolates of $S$. homoeocarpa.

\section{RESULTS}

Laboratory studies. Exposure of isolate S088 to benomyl, chlorothalonil, fenarimol, propiconazole, thiophanate-methyl, or triadimefon resulted in significantly higher $\mathrm{EC}_{50}$ and $\mathrm{EC}_{90}$ values when compared to exposure of isolate S084 (Table 3). The EC values of fluazinam and iprodione were not significantly different for the two isolates.

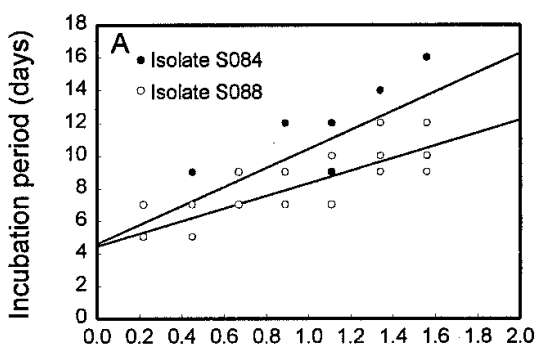

Rate of fluazinam (kg ai ha ${ }^{-1}$ )

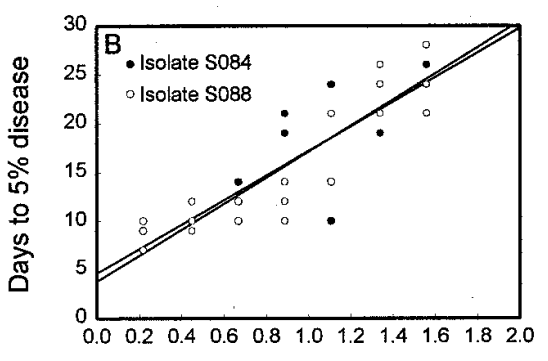

Rate of fluazinam (kg ai ha-1)

Fig. 2. Effect of fluazinam on (A) the incubation periods of isolates of Sclerotinia homoeocarpa that differ in fungicide sensitivity, and on (B) days to 5\% severity of dollar spot caused by the isolates. Lines are regression models: incubation period of isolate $\mathrm{S} 084=4.57+5.85$ (fungicide rate), $r^{2}=0.69$; incubation period of isolate $\mathrm{S} 088=4.43+3.89$ (fungicide rate), $r^{2}=$ 0.70 . Days to $5 \%$ disease caused by isolate $\mathrm{S} 084=4.87+12.58$ (fungicide rate), $r^{2}=0.75$; days to $5 \%$ disease caused by isolate $\mathrm{S} 088=$ $3.85+13.34$ (fungicide rate), $r^{2}=0.82$. Slope coefficients of all models were significant at $P$ $<0.05$.
Field studies. Significant isolate $\times$ fungicide interactions were detected for incubation period and days to $5 \%$ disease in 1994 and 1995 (Table 4). As a result of the interactions, data were analyzed separately for each isolate. In 1994, incubation period of isolate S084 was significantly longer in all treated plots except those treated with iprodione at $1.6 \mathrm{~kg}$ a.i. $\mathrm{ha}^{-1}$, or iprodione + propiconazole at $1.6+0.2 \mathrm{~kg}$ a.i. $\mathrm{ha}^{-1} \mathrm{com}-$ pared to nontreated plots (Table 2). Incubation period of isolate S088 was significantly longer in all plots than in nontreated controls, except in plots treated with thiophanate-methyl. Orthogonal comparisons between isolates in 1994 revealed that incubation period of isolate S088 was significantly shorter than that of S084 in plots treated with propiconazole at 0.2 and 0.8 $\mathrm{kg}$ a.i. $\mathrm{ha}^{-1}$, iprodione + propiconazole at $1.6+0.8 \mathrm{~kg}$ a.i. $\mathrm{ha}^{-1}$, or thiophanate-methyl at 1.6 and $3.2 \mathrm{~kg}$ a.i. ha ${ }^{-1}$ (Table 2).

In 1995, the incubation period of isolate S084 was significantly longer in all fungicide treated plots, compared to nontreated plots, except in those treated with iprodione at 1.6 and $3.1 \mathrm{~kg}$ a.i. ha $^{-1}$ or propiconazole at $0.2 \mathrm{~kg}$ a.i. ha ${ }^{-1}$ (Table 2). Similar effects were observed with isolate S088, and in addition, the incubation period of this isolate was not significantly affected by propiconazole at 0.4 and $0.8 \mathrm{~kg}$ a.i. $\mathrm{ha}^{-1}$ or thiophanate-methyl at 1.5 and $3.0 \mathrm{~kg}$ a.i. $\mathrm{ha}^{-1}$ compared to nontreated controls. Incubation period for isolate S084 was significantly longer than that of isolate S088 in plots treated with propiconazole at $0.4 \mathrm{~kg}$ a.i. ha $^{-1}$ or thiophanate-methyl at 1.5 and $3.0 \mathrm{~kg}$ a.i. ha ${ }^{-1}$ (Table 2).

In turf inoculated with isolate S084 in 1994 , the number of days to reach $5 \%$ disease severity was significantly greater in all fungicide-treated plots than in nontreated controls, except in plots treated with iprodione at $1.6 \mathrm{~kg}$ a.i. ha $\mathrm{ha}^{-1}$ (Table 5). The number of days to reach $5 \%$ disease severity in turf inoculated with isolate S088 was significantly greater in fungicide treated turf than in nontreated turf, except in plots treated with iprodione + propiconazole at $1.6+0.2 \mathrm{~kg}$ a.i. $\mathrm{ha}^{-1}$ or thiophanate-methyl at 1.5 and $3.0 \mathrm{~kg}$ a.i. ha ${ }^{-1}$. Comparisons between isolates in 1994 revealed that the number of days to reach $5 \%$ disease was significantly greater in turf inoculated with isolate S084, compared to isolate $\mathrm{S} 088$, in plots treated with propiconazole at 0.2 and $0.8 \mathrm{~kg}$ a.i. $\mathrm{ha}^{-1}$, thiophanate-methyl at 1.5 and $3.0 \mathrm{~kg}$ a.i. ha ${ }^{-1}$, chlorothalonil + propiconazole at $4.8+0.8$ $\mathrm{kg}$ a.i. $\mathrm{ha}^{-1}$ or iprodione + propiconazole at $1.6+0.8 \mathrm{~kg}$ a.i. ha ${ }^{-1}$ (Table 5). Five treat-

Table 3. Effective concentration (EC) of fungicides required to inhibit the growth of isolates of Sclerotinia homoeocarpa by 50 and $90 \%$

\begin{tabular}{lccr}
\hline Treatment & Isolate & $\mathbf{E C}_{\mathbf{5 0}} \mathbf{y}^{\mathbf{y}}$ & $\mathbf{E C}_{\mathbf{9 0}}^{\mathbf{y}}$ \\
\hline Benomyl & S084 & $0.05 \mathrm{~b}^{\mathbf{z}}$ & $0.33 \mathrm{~b}$ \\
Chlorothalonil & $\mathrm{S} 088$ & $43.67 \mathrm{a}$ & $419.47 \mathrm{a}$ \\
\multirow{3}{*}{ Fenarimol } & $\mathrm{S} 084$ & $0.56 \mathrm{~b}$ & $4.31 \mathrm{~b}$ \\
& $\mathrm{~S} 088$ & $3.41 \mathrm{a}$ & $34.27 \mathrm{a}$ \\
Fluazinam & $\mathrm{S} 084$ & $0.13 \mathrm{~b}$ & $1.81 \mathrm{~b}$ \\
& $\mathrm{~S} 088$ & $5.33 \mathrm{a}$ & $287.22 \mathrm{a}$ \\
Iprodione & $\mathrm{S} 084$ & $0.02 \mathrm{a}$ & $0.21 \mathrm{a}$ \\
& $\mathrm{S} 088$ & $0.02 \mathrm{a}$ & $0.20 \mathrm{a}$ \\
Propiconazole & $\mathrm{S} 084$ & $0.53 \mathrm{a}$ & $15.08 \mathrm{a}$ \\
& $\mathrm{S} 088$ & $0.85 \mathrm{a}$ & $11.07 \mathrm{a}$ \\
Thiophanate-methyl & $\mathrm{S} 084$ & $0.03 \mathrm{~b}$ & $0.16 \mathrm{~b}$ \\
& $\mathrm{~S} 088$ & $0.31 \mathrm{a}$ & $1.37 \mathrm{a}$ \\
Triadimefon & $\mathrm{S} 084$ & $0.06 \mathrm{~b}$ & $0.16 \mathrm{~b}$ \\
& $\mathrm{~S} 088$ & $>1,000.00 \mathrm{a}$ & $>1,000.00 \mathrm{a}$ \\
& $\mathrm{S} 084$ & $0.07 \mathrm{~b}$ & $0.39 \mathrm{~b}$ \\
& $\mathrm{~S} 088$ & $0.50 \mathrm{a}$ & $8.97 \mathrm{a}$ \\
\hline
\end{tabular}

${ }^{y}$ Values are reported as $\mu \mathrm{g} \mathrm{ml}^{-1}$ for all fungicides except fluazinam, which has values reported as $\mathrm{ng}$ $\mathrm{ml}^{-1}$.

${ }^{\mathrm{z}}$ Within each treatment, values followed by the same letter are not significantly different according to an $F$ test from analysis of variance.

Table 4. Significance level $(P)$ from analysis of variance for the effects of fungicides on epidemics of dollar spot in creeping bentgrass caused by isolates of Sclerotinia homoeocarpa that differ in sensitivity in vitro to several fungicides

\begin{tabular}{|c|c|c|c|c|}
\hline$\overline{\text { Year }}$ & Factor & $d f^{y}$ & Incubation period $^{\mathrm{z}}$ & Days to $5 \%$ disease \\
\hline \multirow[t]{3}{*}{1994} & Isolates & 1 & $<0.001$ & $<0.001$ \\
\hline & Fungicides & 12 & $<0.001$ & $<0.001$ \\
\hline & Isolates $\times$ fungicides & 12 & $<0.001$ & $<0.001$ \\
\hline \multirow[t]{3}{*}{1995} & Isolates & 1 & 0.046 & $<0.001$ \\
\hline & Fungicides & 15 & $<0.001$ & $<0.001$ \\
\hline & Isolates $\times$ fungicides & 15 & 0.032 & 0.021 \\
\hline
\end{tabular}

${ }^{y} \mathrm{df}=$ degrees of freedom.

${ }^{z}$ Time (days) from inoculation to visual detection of first dollar spot locus. 
ments that included either propiconazole or thiophanate-methyl suppressed dollar spot severity to less than $5 \%$ for more than 21 days on turf inoculated with isolate S084. In contrast, none of the treatments applied suppressed disease for more than 21 days on turf inoculated with isolate S088.

All treatments in 1995, except chlorothalonil at $4.8 \mathrm{~kg}$ a.i. $\mathrm{ha}^{-1}$, iprodione at 1.6 and $3.1 \mathrm{~kg}$ a.i. $\mathrm{ha}^{-1}$, or propiconazole at 0.2 $\mathrm{kg}$ a.i. $\mathrm{ha}^{-1}$ resulted in a significantly greater number of days to reach $5 \%$ disease severity in turf inoculated with isolate S084 compared to nontreated turf (Table 5). In turf inoculated with isolate S088, the number of days to $5 \%$ disease was significantly greater in all treated plots than in nontreated controls, except in plots treated with iprodione at 1.6 and $3.1 \mathrm{~kg}$ a.i. $\mathrm{ha}^{-1}$, iprodione + propiconazole at $1.6+0.2 \mathrm{~kg}$ a.i. $\mathrm{ha}^{-1}$, or thiophanate-methyl at 1.5 and $3.0 \mathrm{~kg}$ a.i. $\mathrm{ha}^{-1}$. Turf inoculated with isolate S088 reached a threshold of 5\% disease in a significantly fewer number of days than turf inoculated with S084 in plots treated with propiconazole at $0.8 \mathrm{~kg}$ a.i. $\mathrm{ha}^{-1}$, chlorothalonil + propiconazole at $4.8+0.2$ $\mathrm{kg}$ a.i. $\mathrm{ha}^{-1}$, iprodione + propiconazole at $1.6+0.2$ and $1.6+0.8 \mathrm{~kg}$ a.i. $\mathrm{ha}^{-1}$, or thiophanate-methyl at 1.5 and $3.0 \mathrm{~kg}$ a.i. $\mathrm{ha}^{-1}$ (Table 5). Eight treatments in 1995, including fluazinam at 1.6 and $3.2 \mathrm{~kg}$ a.i. ha ${ }^{-1}$, resulted in more than 21 days to reach $5 \%$ disease in turf inoculated with isolate S084; while only the fluazinam treatments resulted in more than 21 days to $5 \%$ disease in turf inoculated with isolate S088 (Table 5).

Linear regression of the incubation period of $S$. homoeocarpa against rate of

Table 5. Effect of fungicides over 2 years on days to $5 \%$ severity of dollar spot in creeping bentgrass inoculated with Sclerotinia homoeocarpa isolates that differ in sensitivity in vitro to several fungicides

\begin{tabular}{|c|c|c|c|c|c|}
\hline \multirow[b]{3}{*}{ Treatment } & \multirow[b]{3}{*}{ Rate (kg a.i. ha-1) } & \multicolumn{4}{|c|}{ Days to $5 \%$ disease severity } \\
\hline & & \multicolumn{2}{|c|}{$1994^{w}$} & \multicolumn{2}{|c|}{$1995^{w}$} \\
\hline & & S084 & S088 & S084 & S088 \\
\hline Chlorothalonil & 4.8 & $13.0 c^{x}$ & $10.5 \mathrm{~b}$ & $14.8 \mathrm{c}$ & $16.3 \mathrm{c}$ \\
\hline Chlorothalonil & 9.5 & $14.5 \mathrm{c}$ & $14.5 \mathrm{a}$ & $16.3 \mathrm{~b}$ & $16.5 \mathrm{c}$ \\
\hline Iprodione & 1.6 & $7.8 \mathrm{e}$ & $8.3 \mathrm{c}$ & $10.8 \mathrm{c}$ & $10.5 \mathrm{~d}$ \\
\hline Iprodione & 3.1 & $9.5 \mathrm{~d}$ & $9.5 \mathrm{c}$ & $11.8 \mathrm{c}$ & $11.0 \mathrm{~d}$ \\
\hline Propiconazole & 0.2 & $13.0 c^{y}$ & $9.0 \mathrm{c}$ & $13.8 \mathrm{c}$ & $14.3 \mathrm{c}$ \\
\hline Propiconazole & 0.4 & $\ldots^{\mathrm{z}}$ & $\ldots$ & $15.8 \mathrm{~b}$ & $13.3 \mathrm{c}$ \\
\hline Propiconazole & 0.8 & $24.0 \mathrm{~b}$ & $11.5 \mathrm{~b}$ & $>29.0 \mathrm{a}$ & $13.8 \mathrm{c}$ \\
\hline Chlorothalonil + propiconazole & $4.8+0.2$ & $14.3 \mathrm{c}$ & $13.3 \mathrm{a}$ & $21.5 \mathrm{~b}$ & $14.3 \mathrm{c}$ \\
\hline Chlorothalonil + propiconazole & $4.8+0.8$ & $24.5 \mathrm{~b}$ & $14.1 \mathrm{a}$ & $>\overline{29.0 \mathrm{a}}$ & $\overline{20.8 b}$ \\
\hline Iprodione + propiconazole & $1.6+0.2$ & $9.8 \mathrm{~d}$ & $\overline{7.3 \mathrm{~d}}$ & $15.8 \mathrm{~b}$ & $11.5 \mathrm{~d}$ \\
\hline Iprodione + propiconazole & $1.6+0.8$ & $24.3 \mathrm{~b}$ & $13.0 \mathrm{a}$ & $21.5 \mathrm{~b}$ & $\overline{14.8 \mathrm{c}}$ \\
\hline Thiophanate-methyl & 1.5 & $\geq \overline{28.0 \mathrm{a}}$ & $7.3 \mathrm{~d}$ & $18.8 \mathrm{~b}$ & $9.0 \mathrm{~d}$ \\
\hline Thiophanate-methyl & 3.0 & $>28.0 \mathrm{a}$ & $\overline{7.1 \mathrm{~d}}$ & $21.5 \mathrm{~b}$ & $\overline{9.3 \mathrm{~d}}$ \\
\hline Fluazinam & 1.6 & $\ldots$ & $\ldots$ & $>\overline{29.0 \mathrm{a}}$ & $>2 \overline{9.0 \mathrm{a}}$ \\
\hline Fluazinam & 3.2 & $\ldots$ & $\ldots$ & $>29.0 \mathrm{a}$ & $>29.0 \mathrm{a}$ \\
\hline Nontreated & $\ldots$ & $7.1 \mathrm{e}$ & $7.5 \mathrm{~d}$ & $11.5 \mathrm{c}$ & $10.0 \mathrm{~d}$ \\
\hline
\end{tabular}

" Isolate S088 was significantly less sensitive in vitro to the fungicides benomyl, chlorothalonil, fenarimol, propiconazole, thiophanate-methyl, and triadimefon than isolate S084.

${ }^{x}$ Within a column, values followed by the same letter are not significantly different at $\alpha=0.05$ according to the Scott-Knott cluster analysis procedure.

${ }^{y}$ Within a treatment, underlined values are significantly different at $P \leq 0.05$ according to orthogonal contrast analysis.

${ }^{z}$ Treatment not applied.

Table 6. Comparisons of slope coefficients from linear regressions between components of disease progress and fungicide concentrations for isolates of Sclerotinia homoeocarpa that differ in sensitivity in vitro to several fungicides

\begin{tabular}{lccc}
\hline Treatment & Component of disease progress & Isolate $^{\mathrm{w}}$ & Slope coefficient \\
\hline Propiconazole & Incubation period & $\mathrm{S} 084$ & $30.16 \mathrm{a}^{\mathrm{x}}$ \\
& & $\mathrm{S} 088$ & $7.25 \mathrm{~b}$ \\
& Days to 5\% disease & $\mathrm{S} 084^{\mathrm{y}}$ & $0.21 \mathrm{~b}$ \\
& & $\mathrm{~S} 088^{\mathrm{z}}$ & $1.41 \mathrm{a}$ \\
Fluazinam & Incubation period & $\mathrm{S} 084$ & $5.85 \mathrm{a}$ \\
& & $\mathrm{S} 088$ & $3.89 \mathrm{a}$ \\
& Days to 5\% disease & $\mathrm{S} 084$ & $12.58 \mathrm{a}$ \\
& & $\mathrm{S} 088$ & $13.34 \mathrm{a}$ \\
\hline
\end{tabular}

w Isolate S088 was significantly less sensitive in vitro to the fungicides benomyl, chlorothalonil, fenarimol, propiconazole, thiophanate-methyl, and triadimefon than isolate S084.

${ }^{x}$ Within each component of disease progress, values followed by the same letter are not significantly different at $\alpha=0.05$ according to an $F$ test from analysis of variance.

${ }^{y}$ Data were transformed with a monomolecular model.

${ }^{\mathrm{z}}$ Data were transformed with an exponential model. propiconazole applied in 1996 showed that rates as low as $0.5 \mathrm{~kg}$ a.i. $\mathrm{ha}^{-1}$ resulted in an incubation period of approximately 15 days for isolate S084 (Fig. 1A). Incubation periods of similar duration were never reached by isolate S088, regardless of fungicide concentration. Similarly, rates as low as $0.3 \mathrm{~kg}$ a.i. $\mathrm{ha}^{-1}$ of propiconazole resulted in a duration of 25 days for isolate S084 to produce $5 \%$ disease severity (Fig. 1B), while a similar duration was never reached in turf inoculated with isolate S088.

Regressions of incubation period and days to $5 \%$ disease severity against concentration of fluazinam showed that the response of isolate $\mathrm{S} 084$ was similar to that of S088 (Fig. 2A and B). Comparisons of slope coefficients of the regressions with propiconazole and fluazinam revealed a significant differential response of the isolates to the former fungicide, but not the latter (Table 6).

\section{DISCUSSION}

Failure to control dollar spot with DMI fungicides representing pyrimidine and triazole groups was first reported in 1992 (12). Confirmation of resistance in isolates of $S$. homoeocarpa was disclosed in 1995 (6). In the earlier report, the authors state "that some of the strains of S. homoeocarpa with the highest level of resistance to the DMI fungicides also have resistance to benzimidazole fungicides (benomyl, methyl-thiophanate, and thiophanate-ethyl) and dicarboximide fungicides (iprodione and vinclozolin)." They go on to reflect that this multiple resistance "may pose the most difficult resistance control problem we (turfgrass managers and pathologists) may yet have to face" (12).

Laboratory and field results indicate that, relative to isolate S084, isolate S088 was resistant to both propiconazole and thiophanate-methyl. Mean $\mathrm{EC}_{50}$ values for DMI-resistant isolates of $S$. homoeocarpa from Michigan and Ohio were greater than $0.5,0.25$, and $0.1 \mu \mathrm{g} \mathrm{ml}^{-1}$ of triadimefon, fenarimol, and propiconazole, respectively (6). In addition, $\mathrm{EC}_{50}$ values greater than 1 $\mu \mathrm{g} \mathrm{ml}^{-1}$ of benomyl were reported for benzimidazole-resistant isolates from Pennsylvania (13). Based on these criteria, isolate S088 would be considered resistant to both groups of fungicides.

The reduced sensitivity of isolate S088 to chlorothalonil in vitro was not evident in the field. Apparently, the difference in sensitivity between S088 and S084 was not great enough to be detected on turf treated with $0.5 \times$ or $1.0 \times$ label rates of chlorothalonil. Data such as these support the need for both in vitro and in planta testing prior to confirming a fungicide resistance problem.

Fluazinam, a nonsystemic, pyridylaniline compound, was the only fungicide tested that suppressed dollar spot caused by either isolate S084 or S088 to a threshold 
of less than $5 \%$ disease for more than 21 days. The dose-response data collected in vitro and in the field in 1996 indicate further that the 2 isolates responded similarly to increasing concentrations of fluazinam. The long-term control of dollar spot provided by fluazinam was surprising for a nonsystemic material. However, due to extremely low inhibitory concentrations $\left(\mathrm{EC}_{50}\right.$ $0.02 \mathrm{ng} \mathrm{ml}^{-1}$ ) residual suppression of fungal growth may be longer than other nonsystemic fungicides on leaves, on shoots, and in turfgrass thatch. Fluazinam will be a useful fungicide for management of dollar spot caused by benzimidazole- and/or DMI-resistant strains of $S$. homoeocarpa.

LITERATURE CITED

1. Beard, J. B. 1982. Turf Management for Golf Courses. Burgess Publishing Co., Minneapo- lis, MN.

2. Burpee, L. L. 1993. A Guide to Integrated Control of Turfgrass Diseases. Vol. 1. Cool Season Turfgrasses. GCSAA Press, Lawrence, KS

3. Burpee, L. L., and Goulty, L. G. 1984. Suppression of brown patch disease of creeping bentgrass by isolates of nonpathogenic Rhizoctonia spp. Phytopathology 74:692-694.

4. Couch, H. B. 1985. Common names of plant diseases. Turfgrass (several cultivated spp.). Plant Dis. 69:672-75.

5. Couch, H. B. 1995. Diseases of Turfgrasses. 3rd ed. Krieger Publishing Co., Malabar, FL.

6. Golembiewski, R. C., Vargas, J. M., Jr., Jones, A. L., and Detweiler, A. R. 1995. Detection of demethylation inhibitor (DMI) resistance in Sclerotinia homoeocarpa populations. Plant Dis. 79:491-493.

7. Horsfall, J. G., and Cowling, E. G. 1978. Pathometry: the measurement of plant disease. Pages 119-136 in: Plant Disease: An Advanced Treatise. Vol. 2, How Disease Develops in Populations. J. G. Horsfall and E.
B. Cowling, eds. Academic Press, New York.

8. Koller, W. 1991. Target Sites of Fungicide Action. CRC, Boca Raton, FL.

9. Neter, J., Wasserman, W., and Kutner, M. H. 1990. Applied Linear Statistical Models: Regression, Analysis of Variance, and Experimental Designs. 3rd ed. Richard D. Irwin, Inc., Homewood, IL.

10. Scott, A. J., and Knott, M. 1974. A cluster analysis method for grouping means in the analysis of variance. Biometrics 30:507-512.

11. Vargas, J. M., Jr. 1994. Management of Turfgrass Diseases. Lewis Publishers, Boca Raton, FL.

12. Vargas, J. M., Jr., Golembiewski, R., and Detweiler, A. R. 1992. Dollar spot resistance to DMI fungicides. Golf Course Management 60 (3):50-54.

13. Warren, C. G., Sanders, P., and Cole, H. 1974. Sclerotinia homoeocarpa tolerance to benzimidazole configuration fungicides. Phytopathology 64:1139-1142. 